Paddy Farrington for the statistical analysis; and Astra Pharmaceuticals who supplied EMLA lignocaine for surface anaesthesia cream.

1 Department of Health and Social Security. Immunisation against infectious disease. London: HMSO, 1988.

2 Department of Health and Social Security. Immunisation against infectious disease. London: HMSO, 1984

Department of Health. Immunisation against infectious disease. London HMSO, 1990.

4 Halsey N, Galazka A. The efficacy of DPT and oral poliomyelitis immunisation schedules initiated from birth to 12 weeks of age. Bull World Health Organ 1985;63:1151-69.

Di Sant Agnese PA. Combined immunisation against diphtheria, tetanus and pertussis in newborn infants. III. Relationship of age to antibody production. Pediatrics 1949:3:333-44.

6 Miller JJ, Faber $\mathrm{HK}$, Ryan ML, et al. Immunisation against pertussis during the first four months of life. Pediatrics 1949;3:468-78.

7 Barrett CD, McLean IW, Molner JG, et al. Multiple antigen immunisation against poliomyelitis, diphtheria, pertussis and tetanus. An evaluation of antibody responses of infants one day old to seven months of age at start of inoculations. Pediatrics 1962;30:720-36.

8 Ministry of Health. On the state of the public health for the year 1967. London HMSO, 1968.

9 Melville-Smith M, Seagroatt VA, Watkins JT. A comparison of the enzymelinked immunosorbent assay (ELISA) with the toxin neutralisation test in mice as a method for the estimation of tetanus antitoxin in human sera. fournal of Biological Standards 1983;11:137-44.
10 Melville-Smith M, Balfour A. Estimation of Corynebacterium diphtheriae antitoxin: a comparison of the enzyme-linked immunosorbent assay (ELISA) with the toxin neutralisation test. I Med Microbiol 1988;25:279-83.

11 Miller E, Ashworth LAE, Robinson A, Waight PA, Irons LI. Double blind phase II trial in three month-old infants of whole cell pertussis vaccine and phase Il trial in three month-old infants of whole cell pertussis vaceil

12 Smith JWG. Diphtheria and tetanus toxoid. Br Med Bull 1969;25:177-82.

13 World Health Organisation. The control of diphtheria in Europe. Report on a WHO meeting. Copenhagen: WHO, 1990

14 Collier LH, Polakoff S, Mortimer J. Reactions and antibody responses to reinforcing doses of adsorbed and plain tetanus vaccines. Lancet 1979; ; 1364-8.

15 Medical Research Council. The prevention of whooping cough by vaccination BMJ 1951;i:1463-71.

16 Noah N. Attack rates of notified whooping cough in immunised and unimmunised children. BMF 1976;i:357-9.

17 Church MA Evidence of whooping-cough-vaccine efficacy from the 1978 whooping-cough epidemic in Hertfordshire. Lancet 1979;ii:188-90.

18 Efficacy of pertussis vaccination in England. Report from the PHLS Epidemiological Research Laboratory and 21 area health authorities. BMF 1982;285:357-9.

19 Cannon DA, Cockburn WC, Evans DG, et al, eds. Proceedings of a symposium on immunisation in childhood. Edinburgh and London: E \& S Livingstone, 1960

20 Jones AE, Johns A, Magrath DI, et al. Durability of immunity to diphtheria tetanus and poliomyelitis after a three dose immunisation schedule completed in the first eight months of life. Vaccine 1989;7:300-2.

(Accepted 24 April 1991)

\title{
Relation between nicotine intake and Alzheimer's disease
}

\author{
Cornelia M van Duijn, Albert Hofman
}

Abstract

Objective-To study the association between Alzheimer's disease and nicotine intake through smoking.

Design-Population based case-control study.

Setting-City of Rotterdam and four northern provinces of The Netherlands.

Subjects-198 patients with early onset Alzheimer's disease, 198 controls matched for age and sex, and families of 17 patients in whom Alzheimer's disease was apparently inherited as an autosomal dominant disorder.

Main outcome measures-Age of onset of dementia, relative risk of Alzheimer's disease.

Results -89 of 193 patients with Alzheimer's disease had a history of smoking compared with 102 of 195 controls. Among the patients and controls with a family history of dementia, smoking was significantly less common in those with dementia (40/95 with dementia $v 55 / 96$ controls; relative risk $0 \cdot 35 ; 95 \%$ confidence interval $0 \cdot 16$ to $0 \cdot 78$ ). The risk of Alzheimer's disease decreased with increasing daily number of cigarettes smoked before onset of disease (relative risk 0.3 in those smoking $>21$ /day $v 1$ in non-smokers). In six families in which the disease was apparently inherited as an autosomal dominant disorder, the mean age of onset was $4 \cdot 17$ years later in smoking patients than in non-smoking patients from the same family $(p=0 \cdot 03)$.

Conclusions - These findings suggest an inverse association between smoking and Alzheimer's disease, although smoking cannot be advocated for other health reasons. We speculate that nicotine may have a role in the aetiology of both Alzheimer's disease and Parkinson's disease.

Biostatistics, Erasmus

University Medical School, PO Box 1738, 3000 DR Rotterdam, The

Netherlands

Cornelia M van Duijn, MSC, resident in epidemiology

Albert Hofman, MD

professor of epidemiology

Correspondence to: Ms van Duijn.

BMF 1991;302:1491-4

\section{Introduction}

Alzheimer's disease and Parkinson's disease have been suggested to have a common aetiology..$^{1-3}$ These neurodegenerative disorders share several pathological and neurochemical characteristics. Lewy bodies, one observed in Alzheimer's disease. ${ }^{2}$ The Alzheimer type pathology is found more often in patients with advanced of the hallmarks of Parkinson's disease, are often idiopathic Parkinson's disease than in the general population. In most studies of Parkinson's disease, patients have been observed to smoke less than control subjects. ${ }^{45}$ There is also some evidence that nicotine may improve information processing and attention in patients with Alzheimer's disease, ${ }^{67}$ which suggests that nicotine may have a protective role in Alzheimer's disease. To test this idea we studied smoking habits before the onset of dementia in patients with Alzheimer's disease and controls as part of a genetic and epidemiological study of Alzheimer's disease carried out in The Netherlands.

\section{Subjects and methods}

The study comprised all patients with Alzheimer's disease living in two areas of The Netherlands in whom the disease was diagnosed before the age of 70 and during January 1980 to July 1987. Ascertainment of patients and controls has been described in detail elsewhere. ${ }^{8}$ For this study the diagnosis of Alzheimer's disease was verified independently and all patients fulfilled the criteria for clinical diagnosis of Alzheimer's disease of the National Institute of Neurological and Communicative Disorders and Stroke and the Alzheimer's Disease and Related Disorders Association (NINCDS-ADRDA). ${ }^{9}$ Dementias other than Alzheimer's disease, such as multi-infarct dementia and dementia secondary to alcoholism, depression, metabolic disorders, epilepsy, and other conditions, were excluded. Patients with symptoms of Parkinson's disease before the onset of Alzheimer's disease were also excluded.

The inclusion criteria for patients were: a score on the clinical dementia rating scale of more than $0.5^{10}$; a score on the short portable mental status questionnaire of less than 20 (out of 30$)^{11}$; a score of seven or less on the Hachinski scale ${ }^{12}$; no evidence of abnormalities on computed tomography other than cerebral atrophy; and no evidence of focal dysfunction on electroencephalography. For each patient, a control matched for age (within five years) and sex was selected randomly from the population registry of the municipality where the patient lived.

Based on patients' family history of dementia 
Alzheimer's disease was classified as sporadic (in those with no first degree relatives with dementia) or familial (in those with one or more first degree relatives with dementia). We examined the pedigree of the families of patients for consistency with autosomal dominant inheritance of Alzheimer's disease. The criteria for autosomal dominant inheritance were at least three family members with reported dementia in two generations and at least two members with detailed records with the clinical diagnosis of Alzheimer's disease. All the relatives of the patients in whom the disease was apparently inherited as an autosomal dominant disorder were screened for dementia." Data on smoking habits and risk factors for Alzheimer's disease were collected for affected and unaffected relatives.

\section{DATA COLLECTION}

We obtained information on putative risk factors for Alzheimer's disease by a structured interview of the next of kin of the patient. To assure symmetry in data collection we also obtained information on the control subject from the next of kin. As aetiological factors were studied questions referred to exposure of the patient before the onset of dementia. Age of onset was defined as the age at which memory failure or changes in behaviour were first noted. For controls a "reference age" was defined on the basis of the age of onset of Alzheimer's disease in the matched case. Patients were classified as non-smokers if they had never smoked before the onset of disease and as smokers if they had ever smoked. Controls were classified similarly based on their smoking habits before the reference age. For smokers the number of cigarettes smoked daily was asked for each period they had smoked. As a measure of the lifetime cigarette exposure, the number of pack years was calculated by multiplying the number of cigarettes smoked a day (in packs) and the duration of cigarette use (in years). Data on smoking history were not available for five patients and three control subjects.

The disease history of patients and controls was evaluated by closed questions with additional open

TABLE I-History of dementia and Parkinson's disease in first degree relatives of patients with Alzheimer's disease and matched controls

\begin{tabular}{|c|c|c|c|c|}
\hline & \multirow[b]{2}{*}{ Patients $(n=198)$} & \multirow[b]{2}{*}{ Controls $(n=198)$} & \multicolumn{2}{|c|}{ Relative risk ( $95 \%$ confidence interval) } \\
\hline & & & Crude & Adjusted $\star$ \\
\hline \multicolumn{5}{|l|}{ Dementia: } \\
\hline $\begin{array}{l}\text { Family history } \\
\text { No family history }\end{array}$ & 96 & 37 & $4 \cdot 12(2 \cdot 61$ to $6 \cdot 43)$ & $4 \cdot 32(2.71$ to $6 \cdot 82)$ \\
\hline \multicolumn{5}{|l|}{ Parkinson's disease: } \\
\hline Family history & 14 & 5 & $2 \cdot 90(1 \cdot 14$ to $8 \cdot 29)$ & $2 \cdot 90(1 \cdot 11$ to $8 \cdot 49)$ \\
\hline No family history & 184 & 193 & & \\
\hline
\end{tabular}

*Adjusted for age, sex, area of residence, and number of first degree relatives by conditional regression analysis. ended questions about medical treatment and admission to hospital. Full pedigree information on dementia and Parkinson's disease was obtained. All first degree relatives were listed, and we asked specifically about the occurrence of dementia and Parkinson's disease in them. To increase the validity of these data the information on family history was verified by a second first degree relative. If the patient had been admitted to hospital the diagnosis was checked in independent medical records. ${ }^{8}$

\section{DATA ANALYSIS}

We assessed the strength of the association between Alzheimer's disease, smoking, and other putative risk factors by the odds ratio as an estimate of the relative risk. ${ }^{13}$ Relative risks are presented with $95 \%$ confidence intervals. Smoking was significantly correlated with alcohol intake $(r=0.34 ; p=0.04)$ in controls, and we therefore used conditional logistic regression analysis to take alcohol consumption as well as sex and age into account. Modification of the relation between smoking and Alzheimer's disease by the established risk factors age, sex, and family history of dementia was tested. As there was a significant interaction between smoking history and family history of dementia $(p=0 \cdot 02)$, we stratified all analyses for family history of dementia. Trends in risk for Alzheimer's disease by categories of smoking were tested by the Mantel test for trend. ${ }^{13}$

The Hachinski score was used to exclude patients with multi-infarct or vascular dementia. ${ }^{12}$ This scale effectively excludes patients with evidence of atherosclerotic cardiovascular disease. Because smoking is associated with cardiovascular disease this may have resulted in lower smoking rates in patients with nonvascular dementia - that is, Alzheimer's disease. To control for this possible bias we performed a separate analysis in which all patients and all controls with a history of atherosclerotic cardiovascular disease, including coronary heart disease, stroke, and hypertension, were excluded.

\section{Results}

Information was available on 198 patients (98\% of the 201 patients eligible for this study). Of the 198 patients with Alzheimer's disease, 74 were men and 124 women. The mean (SD) age of onset of the disease was $56 \cdot 3(6 \cdot 0)$ years in men and $57 \cdot 1(4 \cdot 0)$ years in women. Among controls the first person asked consented in 103 cases, the second person in 68, the third in 23 , and the fourth in four.

Table I shows the family history of dementia and Parkinson's disease of the patients with Alzheimer's disease and their controls. ${ }^{8}$ Of the patients with Alzheimer's disease, $96(48 \%)$ had at least one first degree relative with dementia, compared with 37

TABLE II - History of smoking before the onset of dementia in patients with Alzheimer's disease and matched controls, stratified for history of dementia in first degree relatives

\begin{tabular}{|c|c|c|c|c|c|c|}
\hline & \multicolumn{3}{|r|}{ All subjects } & \multicolumn{3}{|c|}{ Subjects without atherosclerotic cardiovascular disease $†$} \\
\hline & \multirow{2}{*}{$\begin{array}{l}\text { Patients } \\
(\mathrm{n}=193)\end{array}$} & \multirow{2}{*}{$\begin{array}{l}\text { Controls } \\
(\mathrm{n}=195)\end{array}$} & $\begin{array}{c}\text { Relative risk } \\
(95 \% \text { confidence interval) }\end{array}$ & \multirow{2}{*}{$\begin{array}{l}\text { Patients } \\
(n=146)\end{array}$} & \multirow{2}{*}{$\begin{array}{l}\text { Controls } \\
(\mathrm{n}=122)\end{array}$} & $\begin{array}{c}\text { Relative risk } \\
(95 \% \text { confidence interval })\end{array}$ \\
\hline & & & Adjusted $\S$ & & & Adjusted $\S$ \\
\hline \multicolumn{7}{|c|}{ Family history of dementia: } \\
\hline Smoked & 40 & 55 & \multirow[t]{2}{*}{$0.54(0.31$ to 0.96$) 0.35(0.16$ to 0.78$)$} & 27 & 41 & $0.28(0.14$ to 0.59$) 0 \cdot 16(0.06$ to 0.45$)$ \\
\hline Never smoked & 55 & 41 & & 44 & 19 & \\
\hline \multicolumn{7}{|c|}{ No family history of dementia: } \\
\hline Smoked & 49 & 47 & \multirow{2}{*}{$1.11(0.63$ to 1.93$) 1.19(0.63$ to 2.25$)$} & 42 & 32 & \multirow{2}{*}{$1.19(0.61$ to 2.34$) 1.66(0.67$ to 4.13$)$} \\
\hline Never smoked & 49 & 52 & & 33 & 30 & \\
\hline \multicolumn{7}{|l|}{ All patients: } \\
\hline Smoked & 89 & 102 & \multirow[t]{2}{*}{$0.78(0.52$ to 1.16$) 0.70(0.43$ to 1.15$)$} & 69 & 73 & \multirow[t]{2}{*}{$0.60(0.37$ to 0.98$) 0.61(0.31$ to 1.19} \\
\hline Never smoked & 104 & 93 & & 77 & 49 & \\
\hline
\end{tabular}

$\star$ Data were missing for five patients and five controls

†All patients and controls with a history of coronary heart disease, stroke, or hypertension were excluded.

$\ddagger$ Based on unmatched analysis.

SAdjusted for age, sex, residence, and intake of alcohol by conditional logistic regression analysis. 


\begin{tabular}{|c|c|c|c|c|c|c|c|c|}
\hline \multirow[b]{3}{*}{ No of Cigarettes/day } & \multicolumn{4}{|c|}{ All subjects } & \multicolumn{4}{|c|}{ Subjects with family history of dementia } \\
\hline & \multirow{2}{*}{$\begin{array}{l}\text { Patients } \\
(\mathrm{n}=193)\end{array}$} & \multirow{2}{*}{$\begin{array}{l}\text { Controls } \\
(\mathbf{n}=195)\end{array}$} & \multicolumn{2}{|c|}{$\begin{array}{c}\text { Relative risk } \\
\text { (95\% confidence interval) } \\
\end{array}$} & \multirow{2}{*}{$\begin{array}{l}\text { Patients } \\
(\mathbf{n}=95)\end{array}$} & \multirow{2}{*}{$\begin{array}{c}\text { Controls } \\
(n=96)\end{array}$} & \multicolumn{2}{|c|}{$\begin{array}{c}\text { Relative risk } \\
(95 \% \text { confidence interval })\end{array}$} \\
\hline & & & Crude $^{\star}$ & Adjusted $\dagger$ & & & Crude $^{\star}$ & Adjusted $\dagger$ \\
\hline 0 & 104 & 93 & 1 & 1 & 55 & 41 & 1 & 1 \\
\hline $1-10$ & 47 & 46 & $0.91(0.56$ to 1 & $.79(0.46$ to 1.34$)$ & 20 & 25 & $0.60(0.29$ to 1 & $0.46(0.20$ to 1.06$)$ \\
\hline $11-20$ & 27 & 30 & $0.80(0.45$ to 1 & $.59(0.29$ to 1.21$)$ & 13 & 16 & $0.61(0.26$ to 1 & $0.34(0.11$ to 1.05$)$ \\
\hline \multirow{2}{*}{$\begin{array}{l}\geqslant 21 \\
\chi^{2} \text { for trend }\end{array}$} & 15 & 26 & $0.52(0.26$ to 1 & $.39(0.17$ to 0.90$)$ & 7 & 14 & $0.37(0.14$ to 1 & $0.18(0.05$ to 0.69$)$ \\
\hline & & & $5 \cdot 25 ; p=0 \cdot 0$ & & & & $7 \cdot 33 ; p=0 \cdot 0$ & \\
\hline
\end{tabular}

«Based on unmatched analysis

†Adjusted for age, sex, residence, and intake of alcohol by conditional logistic regression analysis.

(19\%) of the controls (relative risk $4 \cdot 32 ; 95 \%$ confidence interval $2 \cdot 71$ to $6 \cdot 82$ ). Significantly more patients with Alzheimer's disease than controls had a first degree relative with Parkinson's disease $(2 \cdot 90 ; 1 \cdot 11$ to 8.49$)$.

Fewer patients with Alzheimer's disease smoked than did control subjects (table II). A significant inverse association with smoking was found in patients with familial Alzheimer's disease (those with one or more first degree relatives with dementia), whereas there was no evidence for an association with smoking in patients with sporadic Alzheimer's disease. The inverse association between familial Alzheimer's disease and smoking remained after restricting the analysis to patients and controls without a history of atherosclerotic cardiovascular disease $(0 \cdot 16 ; 0.06$ to $0 \cdot 45$ ).

A negative trend for smoking was observed when comparing patients with Alzheimer's disease and controls: the risk of Alzheimer's disease decreased as the number of cigarettes smoked daily increased (table III). After exclusion of patients and controls with a history of atherosclerotic cardiovascular disease, the relative risks of Alzheimer's disease for smoking 1-10, $11-20$, and more than 20 cigarettes daily were 0.81 (0.44 to 1.49$), 0.67(0.34$ to 1.32$)$, and $0.26(0.11$ to 0.61 ), respectively. A similar trend was observed when comparing patients and controls for the number of pack years they had smoked. The relative risk of Alzheimer's disease was $0.38(0.13$ to $1 \cdot 10)$ for those who had smoked for 1-10 pack years, $0.29(0.08$ to $0.98)$ for $11-30$ pack years, and $0.22(0.06$ to $0 \cdot 77)$ for more than 30 pack years.

The families of 17 patients had a pedigree consistent with autosomal dominant inheritance of Alzheimer's disease. In these families $18(33 \%)$ of the 56 affected siblings had smoked, compared with $73(67 \%)$ of the 109 unaffected siblings $(0.27 ; 0 \cdot 11$ to 0.67$)$. To test whether smoking history modified the onset of disease, we used the data on six families in which there were patients with Alzheimer's disease who had smoked and patients with Alzheimer's disease who had never smoked (table IV). There was a significantly later onset of $4 \cdot 17$ years in patients who smoked compared with non-smoking patients from the same family (standard error of the difference $1 \cdot 35 ; p=0 \cdot 03$ ).

TABLE IV-Mean age of onset and history of smoking in six families with autosomal dominant inheritance of Alzheimer's disease

\begin{tabular}{lcccc}
\hline & \multicolumn{2}{c}{ Non-smokers } & \multicolumn{2}{c}{ Smokers } \\
\cline { 2 - 3 } Family & No with Alzheimer's disease & $\begin{array}{c}\text { Mean (range) age } \\
\text { of onset (years) }\end{array}$ & No with Alzheimer's disease & $\begin{array}{c}\text { Mean (range) age } \\
\text { of onset (years) }\end{array}$ \\
\hline 1005 & 3 & $55(50$ to 60$)$ & 2 & 62 (61 to 62) \\
1011 & 1 & 62 & 1 & 62 \\
1066 & 3 & $39(38$ to 49$)$ & 2 & 45 (41 to 49) \\
1072 & 1 & 58 & 1 & 63 \\
1083 & 4 & $57(55$ to 63$)$ & 1 & 57 \\
1125 & 1 & 51 & 8 & 58 \\
\hline All families & 13 & $54(38$ to 63) & 1 & $59(41$ to 63)
\end{tabular}

The clinical diagnosis of Alzheimer's disease was confirmed at necropsy in two patients in family 1066 and one patient in family 1072 .

\section{Discussion}

We observed a strong inverse relation between smoking and Alzheimer's disease. The association was restricted to patients with a family history of dementia and was independent of cardiovascular history and potential confounding variables such as age, sex, and alcohol consumption. The risk of Alzheimer's disease decreased as the number of cigarettes smoked daily increased. Within families in which Alzheimer's disease was apparently inherited as an autosomal dominant disorder we observed that the onset of Alzheimer's disease was later in smoking patients than in nonsmoking patients. We also found familial aggregation of Parkinson's disease with Alzheimer's disease, even though patients with Alzheimer's disease who had a history of Parkinson's disease were excluded. ${ }^{8}$

Before interpreting these findings, we would like to raise some methodological issues. At present it is not possible to distinguish between patients with Alzheimer's disease primarily of genetic origin and those with disease primarily of environmental origin. We have therefore classified patients on the basis of their family history of dementia, assuming that patients with a family history are more likely to have disease of genetic origin. This has probably introduced misclassification because relatives of patients with sporadic disease may carry the gene and express the disease later in life, whereas familial aggregation of Alzheimer's disease may be due to clustering of patients with non-genetic disease. The most likely effect of this misclassification is that it has made patients with familial and sporadic disease more similar. The difference in risk between familial and sporadic Alzheimer's disease may therefore be larger than we have reported.

Another methodological issue concerns data collection. Although we measured smoking habits in a symmetrical way in patients and controls, ${ }^{8}$ there is a possibility of bias: the non-response within the control group may have been associated with smoking, and relatives of patients with Alzheimer's disease may have underreported smoking habits. We consider it less likely, however, that these types of bias have occurred only in patients with a family history of dementia or their matched controls. As we observed no association of smoking with sporadic Alzheimer's disease the association with familial Alzheimer's disease is unlikely to be fully explained by these sources of bias. Moreover, the comparison of age of onset between smoking and non-smoking patients largely overcomes the bias to which comparisons of patients with control subjects are prone.

Another possible source of bias is that the survival rate may have been higher in patients who did not smoke than in those who did. However, the association between smoking and familial Alzheimer's disease remained significant after excluding all patients and all controls with a history of atherosclerotic cardiovascular disease, the commonest competing cause of death. Also, the finding of a later onset of disease in smoking 
patients compared with non-smoking patients argues against a clear effect of lower survival among smoking patients.

A final point concerns the uncertainty in the clinical diagnosis of Alzheimer's and Parkinson's diseases. The validity of the diagnosis of dementia and Parkinson's disease in relatives of patients has been discussed elsewhere. ${ }^{8}$ For all patients and controls the data on family history were confirmed by a second first degree relative. The diagnosis of Parkinson's disease could be confirmed by independent medical records for 11 patients $(79 \%)$ and four controls $(80 \%)$.

Previous studies of the association between Alzheimer's disease and smoking have yielded equivocal results. ${ }^{14-26}$ Two studies reported that smoking increased the risk of Alzheimer's disease, ${ }^{1924}$ but in three studies a significant inverse relation was suggested. ${ }^{1+2223}$ Pooling of the data from all formal case-control studies, however, resulted in a significant inverse association (relative risk $=0 \cdot 78 ; 95 \%$ confidence interval 0.62 to 0.98$).^{815-1925.27}$ Our study comprised twice as many patients as the earlier investigations and therefore allows more careful analyses of subgroups and possible sources of bias.

Most studies of cigarette smoking and Parkinson's disease have also reported a protective effect of smoking. ${ }^{4}$ The mechanism underlying the association of smoking with Alzheimer's disease and Parkinson's disease is unclear. In both Alzheimer's disease and Parkinson's disease the number of nicotinic receptors is reduced. ${ }^{28}{ }^{29}$ Decreased binding to nicotinic receptors has been linked to pathological changes characteristic of Alzheimer's disease. ${ }^{3031}$ Nicotine has been reported to increase the density of nicotinic receptors in the brain..$^{32}$ Nicotine from cigarette smoke may compensate for the loss of nicotinic receptors in Alzheimer's disease and Parkinson's disease and thus postpone the onset of disease. However, preclinical changes in nicotinic receptors in patients with Parkinson's disease and familial Alzheimer's disease may have resulted in a loss of desire to smoke in these patients. ${ }^{21}$ The lack of association in patients with sporadic Alzheimer's disease suggests that smoking may be involved only in a mechanism of primarily genetic origin.

Our findings have two implications: firstly, they suggest heterogeneity between familial and sporadic Alzheimer's disease, and, secondly, they suggest a link between Parkinson's disease and familial Alzheimer's disease. Although the association of smoking with familial Alzheimer's disease and Parkinson's disease may be explained by shared pathological characteristics of different aetiology, the familial aggregation of Alzheimer's disease and Parkinson's disease supports the view of a joint pathogenesis. Both findings point to a genetic link between the disorders. For Parkinson's disease as well as familial Alzheimer's disease, it has been suggested that genetic and environmental factors may be implicated. $3: 3:$

Our finding of an inverse association between smoking and Alzheimer's disease should be interpreted with caution as it is not confirmed by prospective studies. Although the association is compatible with a protective effect of smoking for familial Alzheimer's disease, it has no relevance for prevention of Alzheimer's disease because of the adverse health effects of smoking. These findings may lead to interesting speculations, however, about why both familial Alzheimer's and Parkinson's disease may be inversely related to smoking. They may further suggest a joint aetiology of these disorders.

This research was supported by the Steering Committee for
Research on Ageing, The Netherlands Organisation for Scientific Research (NWO), and Eurodem (European Community Concerted Action on the Epidemiology of Dementia). We thank Drs Wim Schulte, Teun Tanja, Rob Haaxma, Arie Lameris, and Rolf Saan for their contributions and Helen de Bruijn, Micheline de Haes, Jeanette Kamman, Hanneke van Meurs, and Caroline Valkenburg for data collection and genealogy studies.

1 Ditter SM, Mirra SS. Neuropathologic and clinical features of Parkinson's disease and Alzheimer's disease. Neurology 1987;37:754-60.

2 Price DL, Whitehouse PJ, Struble RG. Cellular pathology in Alzheimer's and Parkinson's disease. Trends Neurosci 1986;9:29-33.

3 Calne DB, Eisen A, McGeer E, Spencer P. Alzheimer's discase, Parkinson's disease, and motoneuron disease: abiotropic interaction between aging and environment? L ancet 1986;ii: 1067-70.

4 Baron JA. Cigarette smoking and Parkinson's disease. Neurology 1986;36: $1490-6$

5 Hofman A, Collette HJA, Bartelds AIM. Incidence and risk factors of Parkinson's disease in The Netherlands. Neuroepidemiologv 1989:8:296-9.

6 Sahakian B, Jones G, Levy R, Gray J, Warburton D. The effects of nicotine on attention, information processing, and short term memory in patients with dementia of the Alzheimer type. Br F Psychiatry 1989;154:797-800.

7 Newhouse PA, Sunderland T, Tariot PN, Blumhardt CL, Weingartner H, Mellow A, et al. Intravenous nicotine in Alzheimer's disease: a pilot study. Psychopharmacologv 1988;95:171-5.

8 Hofman A, Schulte W, Tanja TA, Van Duijn CM, Haaxma R, Lameris AJ, et al. History of dementia and Parkinson's disease in first degree relatives of patients with Alzheimer's disease. Neurology 1989;39:1589-92.

9 McKhann G, Drachman D, Folstein M, Katzman R, Price D, Stadlan EM. Clinical diagnosis of Alzheimer's disease: report of the NINCDS-ADRDA Work Group. Neurology 1984:34:939-44.

10 Hughes CP, Berg I, Danziger WL, Colen LA, Martin RL. A new clinical scale for the staging of dementia. Br $\mathcal{F}$ Pswchiatry 1982;140:566-72.

11 Pfeiffer $E$. A short portable mental status questionnaire for the assessment of organic brain deficit in elderly patients. F Am Geriatr $S o c$ 1975;23:433-41.
of

12 Hachinski VC, Iliff LD, Zilhka E, Du Boulay GH, McAllister VL, Marshall $\mathrm{J}$, et al. Cerebral blood flow in dementia. Arch Neurol 1975;32:632-7.

13 Schlesselman JJ. Case-control studies. New York: Oxford Universitv Press, 1982

14 Appel SH. Alzheimer's disease. In: Enna SJ, ed. Brain neurotransmitters and receptors in aging and age-related disorders. New York: Raven Press, 1981; 203-7.

15 Heyman A, Wilkinson WE, Stafford JA, Helm KN, Sigmon AN, Weinberg T. Alzheimer's disease: a study of epidemiological aspects. Ann Neurol 1984:15:335-41.

16 French LR, Schuman LM, Mortimer JA, Hutton JT, Boatman RA, Christians B. A case-control study of dementia of the Alzheimer type. Am $f$ Epidemiol 1985;121:414-21.

17 Amaducci LA, Fratiglioni L, Rocca WA, Fieschi C, Livrea P, Pedone D, et al. Risk factors for clinically diagnosed Alzheimer's disease: a case-control Risk factors for clinically diagnosed Alzheimer's dise

18 Chandra V, Philipose V, Bell PA, Lazaroff A, Schoenherg BS. Case-control study of late onset "probable Alzheimer's disease." Neurology 1987;37:12951300 .

19 Shalat SL, Seltzer B, Pidcock C, Baker EL. Risk factors for Alzhcimer's disease: a case-control study. Neurology 1987;37:1630-3.

20 Jones GMM, Reith M. Philpot MP, Sahakian BJ. Smoking and dementia of the Alzheimer type. I Neurol Neurosurg Psychiatry 1987;50:1383.

21 Barclay L, Khevfets S. Tobacco use in Alzheimer's disease. Prog Clin Biol Res $1989 ; 317: 189-94$.

22 Grossberg GT, Nakra R, Woodward V, Russell T. Smoking as a risk factor for Altheimer's disease. F Am Geriatr Soc 1989;37:822.

23 Ferrini-Strambi L, Smirne S, Garanchi P, Pinto P, Francheschi M. Clinical and epidemiological aspects of Alzheimer's disease with presenile onset: a case-control studs. Neuroepidemiology 1990:9:39-49.

24 Joya CJ, Pardo CA, Londono JL. Risk factors in clinically diagnosed Alzheimer's disease: a case-control study in Colombia (South America). Neurobiol Aging 1990):11:296.

25 Broe GA, Henderson AS, Creasev H, McCusker E, Korten AE, Jorm AF, et ul. A case-control study of Alzheimer's disease in Australia. Neurology 1990;40: A case-contro $1698-707$.

26 Graves AB, White E, Koepsell TD, Reifler BV, Van Belle G, I arson EB, et al. A case-control study of Alzheimer's disease. Ann Neurol 1990;28:766-74

27 Graves AB, Van Duijn CM, Chandra V, Fratiglioni L, Heyman A, Jorm AF, et al. Alcohol and tobacco consumption as risk factors for Alzhcimer's disease: a collaborative reanalysis of case-control studies. Int 9 Eptdemiol (in press).

28 Kellar KJ, Whitehouse PJ, Martino-Barrows AM, Marcus K, Price DL. Muscarinic and nicotinic cholinergic binding sites in Alzheimer's disease cerebral cortex. Brain Res 1987;436:62-8.

29 Whitehouse PJ, Martino AM, Wagster MV, Price DL, Mayeux R, Atack JR, et al. Reductions in $[3 \mathrm{H}]$ nicotinic acetylcholine binding in Alzheimer's disease and Parkinson's disease: an autoradiographic study. Neurology 1988:38:720-3.

30) London ED, Ball MJ, Waller B. Nicotinic binding sites in cerebral cortex and hippocampus in Alzheimer's dementia. Neurochem Res 1989;14:745-50.

31 Perry EK, Smith CJ. Perry RH, Johnson M, Fairbairn AF. Nicotinic (3H-nicotine) receptor binding in human brain: characterization and involvement in cholinergic neuropathology. Neurosicence Reseurch Communications 1989;5:117-24

32 Benwell MEM, Balfour DJK, Anderson JM. Evidence that tobacco smoke increases the density of $[\mathrm{H}]$ nicotine binding sites in human brain. 7 Neurochem 1988:50:1243-7.

33 Marsden CD. Parkinson's disease. Lancet 1990;i:948-52.

34 Farrer LA, Myers RH, Cupples L, A, St George-Hystop PH, Bird TD, Rossor MN, et al. Transmission and age at onset patterns in familial Alyheimer's disease: evidence for heterogeneity. Neurologv 1990):40.395-402.

(Accepted 24 April 1991) 